\title{
Building industrial districts: do subsidies help? Evidence from post-war Italy
}

Article

Accepted Version

Spadavecchia, A. (2020) Building industrial districts: do subsidies help? Evidence from post-war Italy. Business History Review, 94 (2). pp. 399-423. ISSN 2044-768X doi: https://doi.org/10.1017/S000768051900117X Available at https://centaur.reading.ac.uk/83073/

It is advisable to refer to the publisher's version if you intend to cite from the work. See Guidance on citing.

To link to this article DOI: http://dx.doi.org/10.1017/S000768051900117X

Publisher: Cambridge University Press

All outputs in CentAUR are protected by Intellectual Property Rights law, including copyright law. Copyright and IPR is retained by the creators or other copyright holders. Terms and conditions for use of this material are defined in the End User Agreement.

\section{www.reading.ac.uk/centaur}

\section{CentAUR}

Central Archive at the University of Reading

Reading's research outputs online 


\title{
Building Industrial Districts: Do Subsidies Help? \\ Evidence from Post-War Italy
}

\author{
Anna Spadavecchia \\ Henley Business School \\ University of Reading
}

The 'historical alternatives' approach advocates research into the role of national institutions and public policies in the resilience, or decline, of industrial districts. Policies in support of small and medium-sized enterprises (SMEs) were launched in various western economies in the second half of the twentieth century. This article focuses on the paradigmatic Italian case, and investigates the impact of government financial subsidies for SMEs on firms located in a southern and a northeastern district, between 1971 and 1991. This discussion deepens our understanding of the role of national policies in the re-emergence of industrial districts in the decades of the 'Second Industrial Divide'. Furthermore, it indicates the importance of firms' utilization of subsidies and their ecosystem as complementary to the policy's effectiveness.

Keywords: small and medium-sized enterprises (SMEs); industrial districts; the 'Second Industrial Divide'; government policies; regional policy.

I thank Ove Bjarnar, Mark Casson, Francesca Carnevali, Evelyn Fenton, Chris Kobrak, Simon Niziol, Alberto Rinaldi, Peter Scott and Michelangelo Vasta for their comments. This article benefited greatly from discussions with Brian A'Hearn, Paolo Di Martino, Oscar Calvo-Gonzalez, Giuliano Maielli and Max-Stephan Schulze. Any errors are my own. 


\section{Building Industrial Districts: Do Subsidies Help? Evidence from Post-War Italy}

The "historical alternatives" approach argues that at any point in history various patterns of business organizations and different combinations of production factors are viable. These might be complementary or competing for inputs and markets. ${ }^{1}$ This article focuses on a pattern of business organization, industrial districts (henceforth districts), that was dominant until the advent of mass production in the nineteenth century and re-emerged during the volatile economic conditions of the 1970s and 1980s. ${ }^{2}$

In explaining the revival of districts in the 1970s and 1980s, identified as the "Second Industrial Divide", the role of national industrial policies seemed negligible, mainly because they were rare, and even detrimental. Even when central governments introduced successful policies for small businesses, these were portrayed as either short-lived, or failing to keep pace with rapidly changing economic scenarios. ${ }^{3}$ However, governments in various western economies introduced policies in favor of small- and medium-sized enterprises (SMEs) in the second half of the twentieth century. The diffusion of such policies calls for research into their impact on districts,

\footnotetext{
${ }^{1}$ Jonathan Zeitlin, "The Historical Alternatives Approach," in Oxford Handbook of Business History, ed. Geoffrey Jones and Jonathan Zeitlin (Oxford, 2008), 120-140; Charles F. Sabel and Jonathan Zeitlin, "Historical Alternatives to Mass Production: Politics, Markets and Technology in NineteenthCentury Industrialization," Past and Present 108 (August, 1985): 133-176.

${ }^{2}$ Michael J. Piore and Charles F. Sabel, The Second Industrial Divide: Possibilities for Prosperity (New York, 1984); Arnaldo Bagnasco, Tre Italie. La Problematica Territoriale dello Sviluppo Italiano (Bologna, 1977); Sebastiano Brusco, "The Emilian Model: Productive Decentralisation and Social Integration," Cambridge Journal of Economics 6 (June 1982): 167-184.

${ }^{3}$ Piore and Sabel, Second Industrial Divide, 304; Peer H. Kristensen and Charles Sabel, "The Smallholder Economy in Denmark: the Exception as Variation," in World of Possibilities, ed. Charles F. Sabel and Jonathan Zeitlin (Cambridge, 1997), 374-378.
} 
and Italy is an ideal case-study given their importance to its economy and the scant research on the role of national institutions in the growth of districts. ${ }^{4}$

This article focuses on a specific tool of government intervention - financial subsidies in the form of soft loans and grants for SMEs, and discusses their importance for two districts: Barletta and San Mauro Pascoli (San Mauro). Both specialized in footwear, one of the "Made in Italy" sectors typical of Italian districts which are also important sources of export revenues. ${ }^{5}$ Barletta is located in southern Italy, whereas San Mauro is in the classical area of industrial districts, the Northeast and Centre, also called "Third Italy" because its pattern of industrialization, i.e. small businesses organized in districts, distinguished it from the northwestern industrial triangle and the under-industrialized South. ${ }^{6}$ Their geographical locations enable comparison of subsidies within the framework of regional policy, the "Extraordinary Intervention for the South," with national industrial policy. Furthermore, this research investigates the much less studied perspective of firms receiving such subsidies, rather than solely the institutional viewpoint. ${ }^{7}$

The 1970s and 1980s were of critical importance for both policies and districts in Italy. Various factors exacerbated the well-known small businesses' financial constraints: instabilities in the credit market, increased prices of inputs and restrictive monetary policies in the 1970 s, as well as the regime of fixed, but adjustable, exchange rates of the European Monetary System in the 1980s. In this context, policymakers perceived subsidized credit as an important compensating mechanism.

\footnotetext{
${ }^{4}$ Jonathan Zeitlin, "Clusters and Industrial Districts," 227-231 in Oxford Handbook of Business History, ed. Geoffrey Jones and Jonathan Zeitlin (Oxford, 2008), 219-243.

${ }^{5}$ Michelangelo Vasta, "Italian Export Capacity in the Long-term Perspective (1861-2009): A Tortuous Path to Stay in Place," Journal of Modern Italian Studies 15, no. 1 (2010): 133-156.

${ }^{6}$ Bagnasco, Tre Italie, 153-162 and 168-184.

${ }^{7}$ For the institutional perspective see Linda Weiss, Creating Capitalism: The State and Small Business since 1945 (Oxford, 1988) and Giuseppe M. Longoni and Alberto Rinaldi, "Industrial Policy and Artisan Firms (1930s-1970s)," in Forms of Enterprise in 20 th Century Italy. Boundaries, Structures and strategies, ed. Andrea Colli and Michelangelo Vasta (Cheltenham, 2010), 204-224.
} 
These were also crucial decades in the regional program for southern Italy, which peaked in the mid-1970s, faced instability in the 1980s, and was finally abandoned in 1993, after the funds allocated to regional policy dried up. Thus, the Census year 1991 closes the research.

This article is organized as follows: the next section provides an overview of the enduring nature of districts and contextualizes the research question. The article then moves on to introduce the plethora of financial schemes for small concerns introduced in Italy in the second half of the twentieth century. The penultimate section analyses the importance of those financial subsidies for the two district cases, and the final section draws the conclusions.

\title{
Industrial Districts as Production Systems
}

\author{
Alfred Marshall observed that late-Victorian British districts were \\ characterized by a concentration of small firms which could offset their \\ disadvantages, as compared to large firms, through external economies and economies \\ of specialization. ${ }^{8}$ The concept of districts or clusters has evolved since its \\ Marshallian formulation and has been discussed from a variety of perspectives. ${ }^{9}$ \\ Districts can be broadly defined as spatial concentrations of interconnected firms, \\ mostly SMEs, specializing in the same industry or producing related goods. This

\footnotetext{
${ }^{8}$ For Marshall's writings on economies arising from the concentration of small firms see his Principles of Economics (1890, Ninth Variorum ed. 1961), vol. 1, 266-271; and also The Early Writings of Alfred Marshall, 1967-1890, ed. J.K. Whitaker (1975), vol. 2, 196-198. cognate concepts see Jonathan Zeitlin, "Industrial Districts'; John F. Wilson and Andrew Popp, "Districts, Networks and Clusters in England: An Introduction," in Industrial Clusters and Regional Business Networks in England, 1750-1970, ed. John F. Wilson and Andrew Popp (Aldershot, 2003), 118; Michael Porter and Christian Ketels, "Clusters and Industrial Districts: Common Roots, Different De Propris, (Cheltenham, 2009), 172-183. For a review of approaches see Valeria Giacomin, "A Historical Approach to Clustering in Emerging Economies," 2017, Harvard Business School Working Paper 18-018.
} \\ ${ }^{9}$ The concepts of industrial districts and cluster have different emphases. For a discussion of these \\ Perspectives," in A Handbook of Industrial Districts, ed. Giacomo Becattini, Marco Bellandi and Lisa
}


system of production is typically embedded in the local socio-cultural context, creating a mutually reinforcing dynamic. ${ }^{10}$

The district pattern of business organization, which Philip Scranton defined as "the other side of the Second Industrial Revolution," waned with the emergence of mass production. For instance, networked textile producers in Philadelphia declined because they could not compete with large-scale distribution via department stores and chains. Such a "buyer market" led to a decline in products' style and technical advantages, a separation of design from manufacturing, and relegated specialists to niches. ${ }^{11}$ In other instances, such as bicycle manufacturing in Birmingham, small independent workshops moved to mass production in search of new markets following the Great Depression. The blueprints for standardized goods were provided by the dominant firms, thus the metalworking workshops lost their ability to design and produce independently. ${ }^{12}$

Other districts thrived, however. This was the case of Grand Rapids" "styled furniture" and the machine-tool industry in Cincinnati. Both districts, albeit hit by the Great Depression, managed to prosper, developing innovative processes and products..$^{13}$ Although experiencing economic downturns, the district of Oyonnax in France, a production center of boxwood combs in the early nineteenth century, thrived to become a center specialized in the production of plastic moulds, serving customers all over the world. ${ }^{14}$ The silk-weaving districts of Kiryu in Japan, where the

\footnotetext{
${ }^{10}$ Michael J. Enright, "Organization and Coordination in Geographically Concentrated Industries," in Coordination and Information: Historical Perspectives on the Organization of Enterprise, ed. Naomi R. Lamoreaux and Daniel M. G. Raff (Chicago, 1995), 103-142; Giacomo Becattini, "The Marshallian Industrial District as a Socio-Economic Notion," in Industrial Districts and Inter-Firm Co-operation in Italy, Frank Pyke, Giacomo Becattini and Werner Sengenberger, (Geneva, 1990), 37-51.

${ }^{11}$ Philip Scranton, Endless Novelty: Specialty Production and American Industrialization, 1865-1925

(Princeton, 1997), 349.

${ }^{12}$ Sabel and Zeitlin, "Historical Alternatives," 160.

${ }^{13}$ Scranton, Endless Novelty, 349-350.

${ }^{14}$ Jean Saglio, "Local Industry and Actors' Strategies: From Combs to Plastics in Oyonnaux," in World of Possibilities: Flexibility and Mass Production in Western Industrialization, ed. Charles F. Sabel and
} 
manufacture of high-quality silk dates to the seventeenth century, overcame challenges through constant innovation of products and processes, and an effective governance structure. ${ }^{15}$

Since the late nineteenth century, the "First Industrial Divide", the two systems of flexible specialization and mass production have competed, monitored, and learned from one another, producing hybrid forms such as flexible massproduction, and adapting innovations from large to small-scale production. ${ }^{16}$ However, victories on either side proved only temporary. When districts declined, supporters of flexible specialization claim this was not due to the exhaustion of technological possibilities and lack of competitiveness, but rather to social, political, and economic forces supporting mass production. ${ }^{17}$ This interpretation is not uncontroversial, as critics claim that reducing production costs per unit is necessary in order to meet the limited purchasing power of the majority of consumers. Furthermore, economies of scale are fundamental in various heavy industries, which are major contributors to industrialization and growth. ${ }^{18}$

A clear manifestation of forces favorable to mass production occurred in the post-World War II period, when national governments supported the introduction of mass production techniques and the paradigmatic American organization of production. These were considered essential for the international competitiveness of

\footnotetext{
Jonathan Zeitlin (Cambridge, 1997), 419-460.

15 Tomoko Hashino and Takafumi Kurosawa, "Beyond Marshallian Agglomeration Economies: The Roles of Trade Associations in Meiji Japan,” Business History Review 87 (Autumn 2013): 489-513; Hideki Yamawaki, "The Evolution and Structure of Industrial Clusters in Japan," Small Business Economics 18 (February 2002): 121-140.

${ }^{16}$ Zeitlin, "Historical Alternatives,” 124-125.

${ }^{17}$ Piore and Sabel, Second Industrial Divide, 21 and 163-164; Charles F. Sabel and Jonathan Zeitlin, "Stories, Strategies, Structures: Rethinking Historical Alternatives to Mass Production," in World of Possibilities, ed. Sabel and Zeitlin, 1-33.

18 Compare Zeitlin 'Historical Alternatives' and David S. Landes, "Small is Beautiful. Small is Beautiful?," in Piccola e Grande Impresa: un Problema Storico, ed. Fondazione ASSI/Istituto per la Storia dell'Umbria Contemporanea (Milan, 1987), 15-28.
} 
national economies. ${ }^{19}$ States used fiscal and monetary policies to stabilize demand to induce firms to expand and increase investment and output. ${ }^{20}$ Michael J. Piore and Charles F. Sabel attribute to national governments an important role in forging mass markets and favoring mass-producing firms, particularly in Japan, Germany, Italy, and France. ${ }^{21}$ However, mass production techniques were not the only possible path towards economic growth and international competitiveness. In the post-World War II decades, many firms and regions enjoyed economic success by basing their competitive strengths on economies of specialization, and strategies of flexible specialization by adjusting output and introducing new products (or versions of products) in response to changing demand and in an effort to create a varied demand through constant innovation. ${ }^{22}$

The resilience of the district as a pattern of business organization and its economic importance became particularly noticeable in the unstable economic conditions of the 1970s and 1980s, when districts proved able to thrive in a market characterized by segmented and fluctuating demand. ${ }^{23}$ It was at this stage that districts in Italy, as well as in other European countries and in Japan, attracted the attention of sociologists, historians, and economists. Attention fell not only on established historical districts, but also later ones, contributing to outstanding economic growth of their regions, such as the Correggio plastic district near Reggio Emilia (Northeast region of Italy), medical instruments in Mannheim (Baden-Wuttemberg region in

\footnotetext{
${ }^{19}$ Piore and Sabel, Second Industrial Divide, 163.

${ }^{20}$ Charles F. Sabel, "Flexible Specialisation and the Re-emergence of Regional Economies," 18 in Reversing Industrial Decline? Industrial Structure and Policy in Britain and Her Competitors, ed. Paul Hirst and Jonathan Zeitlin (Oxford, 1989), 17-70; Zeitlin, "Historical Alternatives," 126.

${ }^{21}$ Piore and Sabel, Second Industrial Divide, 157; Bernard Ganne, "Industrial Development and Local Industrial Systems in Postwar France," in: Pathways to Industrialization and Regional Development, ed. Michael Storper and Allen J. Scott (London and New York, 1992), 216-252.

${ }^{22}$ Zeitlin, "Historical Alternatives".

${ }^{23}$ Zeitlin, "Industrial Districts"; Sabel, "Flexible Specialisation".
} 
Germany), and the furniture district in Salling (West Jutland in Denmark). ${ }^{24}$ The growth of districts was also related to the restructuring of large corporations and their outsourcing to localized suppliers, following labor rigidities in the late 1960s in various countries, and the oil shocks of the $1970 \mathrm{~s} .{ }^{25}$

An under-investigated factor in this revival is that a number of countries introduced policy measures in favor of small businesses. In Japan specialized financing institutions began to operate after World War II when the government launched schemes providing financial assistance and training to SMEs in the automotive and machine-tools industries. ${ }^{26}$ West Germany's government provided low interest loans for small enterprises under the European Recovery Program. These funds, which were repaid and re-lent, continued to be important for SMEs even in the 1980s. ${ }^{27}$ Moreover, additional schemes were introduced in subsequent years, which were extended to the whole country after its reunification. ${ }^{28}$ Similarly, the French government encouraged the establishment of the Companies for Regional Development, which acquired minority interests in regional SMEs and provided longterm loans. However, their operations developed slowly and, following the crises of

\footnotetext{
24 Pier Paolo Patruco, "The Emergence of Technology Systems: Knowledge Production and Distribution in the Case of the Emilian Plastics District," Cambridge Journal of Economics 29, no.1 (2005): 37-56; Bjørn Asheim and Lars Coenen, "Knowledge Bases And Regional Innovation Systems: Comparing Nordic Clusters," Research Policy 34, no.8 (2005): 1173-1190; Thomas Brenner, "Identification of Local Industrial Clusters in Germany," Regional Studies 40, no.6 (2006): 991-1004; Regional Cluster Atlas Baden-Wurttenberg, 2016, www.cluster-portal-bw.de (accessed on 21 August 2018).

25 Bennet Harrison, Lean and Mean. The Changing Landscape of Corporate Power in the Age of Flexibility (New York, 1994), 37-52 and 134-135; Gary Loveman and Werner Sengenberger "The Reemergence of Small-Scale Production: An International Comparison," Small Business Economics 3, no.1 (1991): 1-37.

26 Yuko Aoyama, "Policy Intervention for Industrial Network Formation: Contrasting Historical Underpinnings of the Small Business Policy in Japan and the United States," Small Business Economics 12, no. 3 (1999): 217-231.

${ }^{27}$ Ulrich Wengenroth, "Small-scale Business in Germany," 123-124 in Small Firms, Large Concerns. The Development of Small Business in Comparative Perspective, ed. Konosuke Odaka and Minoru Sawai (Oxford, 1999), 117-139.

${ }^{28}$ Stephanie Weimer, "Federal Republic of Germany," 136 in The Re-emergence of Small Enterprises. Industrial Restructuring in Industrialised Countries, ed. Werner Sengenberger, Gary W. Loveman and Michael J. Piore (Geneva, 1990), 98-143; Dirk Czarnitski, "Research and Development in Small and Medium Sized Enterprises: the Role of Financial Constraints and Public Funding," Scottish Journal of Political Economy 53, no.3 (2006): 335-357.
} 
the 1970s and a contraction of SMEs' own capital, the government introduced direct financial subsidies, such as soft loans and tax breaks, in addition to supporting the development of SMEs' technological capabilities. ${ }^{29}$

The US government also introduced measures in favor of small businesses: the Small Business Administration (SBA) was established in 1953, resulting from the amalgamation of pre-existing federal agencies. Congress passed the Small Business Investment Act in 1958, which placed Small Business Investment Corporations (SBICs) under the SBA's control..$^{30}$ The purpose of SBICs was to ensure supply of long-term and equity capital to SMEs, being aware that the limited availability of capital hampered SMEs' growth. ${ }^{31}$

Policies for SMEs might have been overlooked because they were regarded as too generic in explaining districts' emergence in specific locations. ${ }^{32}$ This is a valid view, considering the variety of contributory factors to the growth of districts. However, it does not seem a sufficient reason to dismiss a priori a possible contribution of the policies to the growth of district firms. ${ }^{33}$ Industrial districts interact dynamically with the broader institutional and economic environment, and this interaction is deemed as requiring further investigation. ${ }^{34}$ Recent work has examined the role of institutions in shaping the governance and structure of clusters in developing countries, while a rich contemporary literature in economic geography,

\footnotetext{
${ }^{29}$ Michele Lescure, "SMEs in France, 1900-1975," 160-162 in Small Firms, Large Concerns, ed. Odaka and Sawai (Oxford, 1999), 140-167. Rachel Parker, "From National Champions to Small and Medium Sized Enterprises: Changing Policy Emphasis in France, Germany and Sweden”, Journal of Public Policy 19, no. 1 (1999): 63-89.

${ }^{30}$ Bernard L. Boutin, "Small Business Loans from Government Sources," in Financing of Small Business: A Current Assessment, ed. Irving Pfeffer (New York, 1967), 314-332; Mansel G. Blackford, A History of Small Business in America (Chapel Hill, 2003), 134-137.

${ }^{31}$ Boutin, "Small Business"; Blackford, A History, 135; Martin Kenney and Richard Florida, "Venture Capital in Silicon Valley: Fuelling New Firm Formation," in Understanding Silicon Valley: The Anatomy of an Entrepreneurial Region, ed. Martin Kenney (Stanford, 2000), 98-123.

${ }^{32}$ Carlo Trigiglia, Sviluppo senza Autonomia; Effetti Perversi delle Politiche nel Mezzogiorno (Bologna, 1992).

${ }^{33}$ Weiss, Creating Capitalism; Anna Spadavecchia, "Financing Industrial Districts in Italy: A Private Venture?," Business History 47, no. 4 (2005): 569-593.

${ }^{34}$ Zeitlin, "Industrial Districts," 227-231.
} 
policy and entrepreneurship analyses the impact of government policies on the development of clusters. ${ }^{35}$

Nevertheless, the historical role of national policies in the paradigmatic case of Italian districts has attracted little attention, as Jonathan Zeitlin points out. Researchers have stressed the importance of local banks, not only for the provision of capital, but also as coordinators of the local financial system, and of circuits of credit internal to the districts. ${ }^{36}$ However, criticisms have been leveled at other types of government policies, such as granting favorable legal conditions to small concerns, because these provided perverse incentives to firms to remain small, rather than pursuing growth opportunities, thus distorting the country's industrial structure. ${ }^{37}$ This article focuses on a specific type of government intervention - financial subsidies in the form of soft loans and grants. These were major policy instruments aimed at stimulating recipient firms' investment and growth, and therefore a form of government intervention which might have contributed directly to the growth of district firms. ${ }^{38}$

\section{Government Subsidies for Small Businesses}

\footnotetext{
${ }^{35}$ Valeria Giacomin, "Negotiating Cluster Boundaries: Governance Shifts in the Palm Oil and Rubber Cluster in Malay(si)a (1945-1970 ca.)," Management and Organizational History 12, no.1 (2017): 7698; See for instance articles in journals such as Journal of Economic Geography, Regional Studies; Research Policy and Small Business Economics.

${ }^{36}$ Francesca Carnevali, Europe's Advantage (Oxford, 2005); Giuseppe Conti and Giovanni Ferri, "Banche Locali e Sviluppo Economico Decentrato" in Storia del Capitalismo Italiano dal Dopoguerra a Oggi, ed. Fabrizio Barca (Rome, 1997), 429-465. Gabi Dei Ottati, "Trust, Interlinking Transactions and Credit in the Industrial District," Cambridge Journal of Economics 18 (December 1994): 529-546.

${ }^{37}$ Paolo Di Martino and Michelangelo Vasta, "Reassessing the Italian 'Economic Miracle': Law, Firms' Governance, and Management, 1950-1973,’Business History Review 92, (Summer, 2018): 281306.

${ }^{38}$ Stimulating investment was by far the largest single area of policy intervention in favor of SMEs in the OECD countries. Other policy tools included: administrative and fiscal measures, such as reduced employment contributions and tax breaks, training and mentoring schemes, loan guarantees for startups. Organisation for Economic Cooperation and Development (OECD), Small Businesses, Job Creation and Growth: Facts, Obstacles and Best Practices (Paris, 1997), 27.
} 
Italy was no exception in relying on large corporations to assure the international competitiveness of the national economy in the late 1940s and early 1950s, with state-owned large enterprises in mechanics, metalworking and chemicals playing an important role. ${ }^{39}$ However, policy makers were also aware of the weight of small businesses in the country's industrial structure, although not every political party saw them as an asset. The ruling Christian Democratic Party (DC for its Italian acronym) supported SMEs for economic and socio-political motivations. It considered small concerns as a path to economic development, capable of adopting new technologies, and essential for a cohesive society, rather than one polarized between owners of means of production and unionized laborers. ${ }^{40}$ The Communist Party (PCI) regarded small firms as economically inefficient and as the initial stage of enterprises, which would either grow or eventually fold; nevertheless, their presence avoided economic stagnation. Moreover, supporting the middle class was instrumental in avoiding their being influenced by a rightist ideology. ${ }^{41}$ Furthermore, SMEs had produced intermediate institutions such as the "Italian Confederation of Small and Medium Firms" (CONFAPI) in 1947, which was effective in promoting the interests of their members and expressing their difficulties in accessing market finance. ${ }^{42}$

The DC support and the skepticism of the PCI and the Socialist Party (PSI) informed parliamentary debate on the bill which established the Regional Mediumterm Credit Institutions (RMCIs) in 1950. These specialized in the provision of

\footnotetext{
${ }^{39}$ Franco Amatori, Matteo Bugamelli and Andrea Colli (2013), "Technology, Firms Size, and Entrepreneurship," in The Oxford Handbook of the Italian Economy since Unification, ed. Gianni Toniolo, (Oxford, 2013), 455-484.

${ }^{40}$ Alberto Rinaldi and Anna Spadavecchia, "The Political Economy of Financing Italian Small Businesses, 1950-1990s," in People, Places and Business Cultures: Essays in Honour of Francesca Carnevali, ed. Paolo Di Martino, Andrew Popp, and Peter Scott (Martlesham, 2017) 55-74, and bibliography therein. Weiss, Creating Capitalism, 55-80, 104-126; Paolo Peluffo and Vladimiro Giacché, Storia del Mediocredito Centrale (Rome-Bari, 1997), 5-9.

${ }^{41}$ Rinaldi and Spadavecchia, "The Political Economy"and bibliography therein.

${ }^{42}$ CERPI, Il Finanziamento alle Piccole e Medie Imprese in Italia, (Milano, 1973), vii and 112.
} 
medium-term credit, defined as longer than one year, to SMEs. ${ }^{43}$ DC representatives articulated the economic rationale of small industrial concerns and of a financial system geared towards them. ${ }^{44}$ The DC Minister of Industry, Togni, stressed the socio-economic purpose of credit and its importance for achieving "the common good." ${ }^{45}$ In opposition, representatives of the PSI stressed that small businesses were not competitive and were destined to be absorbed into large concerns. The law very often mentions "small and medium-sized business," but it does not specify their size. The scheme, aimed at directing credit to SMEs, established a ceiling of 15 million lire (US\$ 311,000 in 2016 prices) for loans, which increased to 50 million lire in 1954 (\$865,018/2016). ${ }^{46}$ The financial structure of the RMCIs reached completion two years later, with the establishment of their refinancing institution, the Mediocredito Centrale, supported especially by the DC government led by De Gasperi (1945-1953), the Association of Industrialists (Confindustria), and Menichella, the governor of the Bank of Italy (1946-1960). ${ }^{47}$

The DC Minister of Industry, Colombo, proposed a generous soft-loan scheme for SMEs in 1959. Various political parties, including the PCI and PSI, agreed on the aims of the bill, and debate focused on an effective implementation of the scheme, such as only targeting SMEs. Fixing a ceiling on the loans initially addressed this issue. ${ }^{48}$ Subsequent decrees specified the size limit of SMEs, defined as having

\footnotetext{
${ }^{43}$ For the distinction between short-term credit (up to one year), and medium (above one year) see Giandomenico Piluso, "From the Universal Bank to the Universal Bank: A Reappraisal," Journal of Modern Italian Studies 15, no.1 (2010): 84-103.

${ }^{44}$ Senato della Repubblica, IX Commissione Industria, Commercio Interno ed Estero, e Turismo, Riunione del 1 Giugno 1950.

${ }^{45}$ Peluffo and Giacché, Storia del Mediocredito, 6-18.

${ }^{46}$ Associazione Bancaria Italiana (ABI), La Legislazione Italiana sul Credito Speciale all'Industria e al Commercio (Roma, 1963), 179-180.

${ }^{47}$ Peluffo and Giacché, Storia del Mediocredito, 31-36.

${ }^{48}$ Camera dei Deputati, Discussione del Disegno di Legge 1494, 23-24 Luglio 1959.
} 
fewer than 500 workers and $3 \mathrm{bn}$ lira in fixed and circulating capital (\$45.2 million/2016), but with ad hoc criteria for the South. ${ }^{49}$

The disadvantages faced by small businesses in accessing market finance were even more pronounced in the south, since capital scarcity is a typical feature of underdevelopment. Subsidies to southern SMEs began in 1957 through the regional policy for southern Italy, managed by a dedicated institution: the Cassa per il Mezzogiorno (Cassa). The post-World War II plan of promoting industrialization in southern regions had as its advocates both managers and economists at the stateowned Institute for Industrial Reconstruction, and at the Bank of Italy, as well as the socialist Minister of Industry, Morandi. ${ }^{50}$ The program gained domestic and international support. The International Bank for Reconstruction and Development actively participated in its design and implementation because it considered the development of southern Italy essential to the reconstruction and modernization of the country's economy. ${ }^{51}$

Cassa's subsidies, grants, and soft loans initially targeted SMEs, meeting defined size limits (fewer than 500 workers and fixed capital below 3 bn lire, equivalent to $\$ 47.2$ million/2016), but soon those limits disappeared, so that by 1959 any firm could benefit from financial subsidies on the first 6bn lire $(\$ 90.4$ million/2016) of their investment. This change marked a diversion of the regional policy's initial intention to develop an organic network of SMEs, because of the need to attract modern industries and large investment from the North. In addition to the major national programs, schemes addressing specific and sectoral problems appeared

\footnotetext{
${ }^{49}$ CERPI, Il Finanziamento, 30.

${ }^{50}$ Amedeo Lepore, "Cassa per il Mezzogiorno e Politiche per lo Sviluppo," in Istituzioni ed Economia, ed. Andrea Leonardi (Bari, 2011), 107-165.

${ }^{51}$ Leandra D'Antone, “<<Straordinarietà $>>$ e Stato Ordinario," in Storia del Capitalismo Italiano, ed. Fabrizio Barca (Rome, 1997), 579-625; Michele Alacevich, "Postwar Development in the Italian Mezzogiorno: Analyses and Policies,” Journal of Modern Italian Studies 18, no. 1 (2013): 90-112.
} 
in subsequent years. The lack of a coherent industrial policy is one interpretation of the proliferation of subsidies, later called a "jungle of incentives," by which the same firm could benefit from several schemes. ${ }^{52}$

The Central Bank also introduced measures to shelter small businesses from credit squeezes. This was the case in the 1970 s when, due to high inflation and negative interest rates (1973-75), banks preferred lending at higher interest rates on the short-term market. ${ }^{53}$ To redirect money into the medium-term market the central bank introduced measures such as the "portfolio obligation" in 1973, and from 197378, imposed ceilings on loans, except for those below 500 million lira (\$4.1million/2016), to ensure a flow of credit towards small firms. ${ }^{54}$

Subsidized credit acquired greater importance as a corrective mechanism to facilitate firms' access to credit in the deteriorating economic conditions following the first oil-shock. ${ }^{55}$ A simplification of the soft loan system followed the 1975 recession, when Italian GDP fell by 2.1 percent, the first fall since World War II. ${ }^{56}$ One single scheme (law 902/76) supplanted various earlier ones, and provided subsidized credit throughout the country on progressively preferential conditions for less developed regions. The DC government, led by the PM Andreotti, proposed the bill, gaining support from other political parties. MPs across the political spectrum raised issues concerning the administration of subsidies, such as delays in extending approved

\footnotetext{
52 Giovanni Federico and Renato Giannetti, "Italy: Stalling and Surpassing," in European Industrial Policy: The Twentieth-Century Experience, ed. James Foreman-Peck and Giovanni Federico (Oxford, 1999), 124-151. A body of research interprets the lack of a coherent industrial policy as a result of various governments' inability to reform the state and its apparatus. See Di Martino and Vasta, "Reassessing the Italian 'Economic Miracle," and bibliography therein.

${ }^{53}$ Fratianni and Spinelli, A Monetary History, 228-233; Harold James, Europe Reborn: A History, 1914-2000 (Harlow, 2003), 334-335.

${ }^{54}$ Davide Croff and Franco Passacantando, "Il controllo diretto del credito," in La politica monetaria in Italia. Istituti e strumenti, ed. Franco Cotula and Pietro de' Stefani (Bologna, 1979), 563-585.

${ }^{55}$ Francesco Vassalli and Giuliano Visentini, Legislazione Economica, Settembre 1976- Agosto 1977 (Milan, 1978), 27-30.

${ }^{56}$ Alberto Baffigi, Stephen N. Broadberry, Claire Giordano and Francesco Zollino, "Data Appendix Italy's National Accounts (1861-2010)," in The Oxford Handbook of the Italian Economy since Unification, ed. Gianni Toniolo (Oxford, 2013), 631-712.
} 
loans and the lack of a clear definition of the size of beneficiary firms, to prevent larger concerns from accessing this scheme. Thus, the bill fixed the upper limit of eligible firms to $1.2 \mathrm{bn}$ lire in fixed assets (\$6million/2016) and up to 300 employees. ${ }^{57}$

The 1980s saw an emphasis on measures promoting innovation, particularly with laws 46/1982 and 696/1983, which subsidized technological innovation within firms of any size and the adoption of high-tech equipment in SMEs, respectively. The SME scheme, proposed by various ministers of the coalition government led by the Socialist PM, Craxi, provided grants for the purchase and leasing of high-tech equipment. Parliamentary debate, which focused only on its management, displayed wide support for this scheme. Precise identification of the beneficiaries was one of the issues raised; the solution was the adoption of the SME definition specified in previous schemes..$^{58}$

The "Extraordinary Intervention for the South" underwent a period of instability between 1980 and 1986, when eleven ministerial decrees prolonged the program. Political parties agreed to maintain an additional flow of resources to the South, but there was disagreement concerning the institutional framework of these funds. In 1986 the regional program received further finance extending its life until 1993, when domestic and external pressures halted the flow of funding. There was resentment in the North about the level of public expenditure in the South. The policy appeared as a drain on the northern economy and in forty years it had achieved few tangible results. In addition, there was growing antipathy towards the role of the public administration in the Italian economy and the institutional structure operating the Mezzogiorno policy. The European Commission also influenced the course of

\footnotetext{
${ }^{57}$ Camera dei Deputati, Commissione XII Industria, Artigianato e Commercio con l'Estero, 27 April 1978.

${ }^{58}$ In particular the definition specificied in law 675/1977. Camera dei Deputati, Seduta 3 Novembre 1983; Law 19 Dicembre 1983, n. 696.
} 
events by refusing to approve the 1992 bill to refinance the program. In December 1992 the Italian Parliament decided to abolish the "Extraordinary Intervention" and its institutions, replacing the policy with a national program of assistance for depressed areas. $^{59}$

\section{The Importance of Subsidies for Barletta and San Mauro Pascoli}

A handicraft tradition in footwear emerged in the districts of Barletta, in Puglia and San Mauro, in Emilia Romagna (see Map 1), at the beginning of the twentieth century.

\footnotetext{
59 Salvatore Cafiero, Storia dell'Intervento Straordinario nel Mezzogiorno (1950-1993) (ManduriaBari-Rome, 2000).
} 


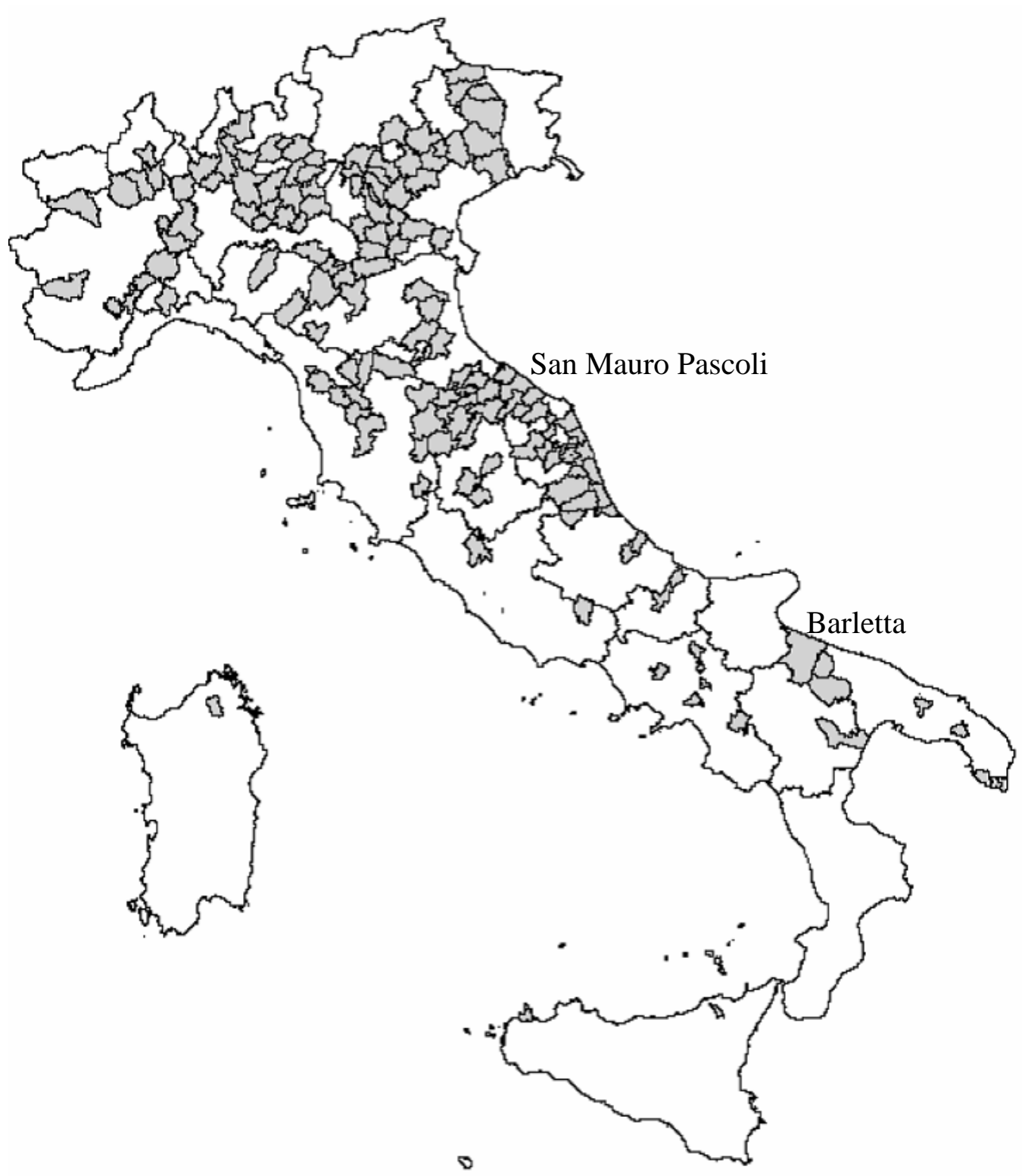

Map 1. Italian industrial districts, 2001. (Source: Istituto Nazionale di Statistica, Distretti Industriali e Sistemi Locali del Lavoro 2001, Rome, 152.)

Over time the two areas specialized in different segments of the industry: medium and high segments of leather footwear in San Mauro, and low and medium segments of leisure footwear in Barletta, where firms specialized in rubber-soled footwear mainly because of a scarcity in alternative raw materials, such as leather. This was the case in one of the currently largest firms (included in the sample), Cofra, 
established in 1938 by Ruggiero Cortellino. Industrial production began in Barletta after World War II with Calzaturificio Giuseppe Damato Ltd, also in the sample. The success of the firm was evident in the district and had a demonstration effect. Barletta and surrounding municipalities developed additional specializations in clothing and textiles, which had started in the interwar period and benefited from military orders during World War II. The industry grew in the 1950s and 1960s and numerous spinoffs occurred, particularly in the fast-growth period of the 1970s and 1980s. Among these spinoffs were the firms Ripatex and Magia, both included in the data sample. ${ }^{60}$

The 1970s and 1980s were Barletta's "Golden Age" when new equipment and raw material were introduced which led to additional specializations in the mediumlow segment of sport and leisure footwear. Firms were able to purchase new equipment owing to suppliers' favorable payment terms and subsidies extended in the context of the regional policy, which was crucial at a time of restrictive monetary policy of the late 1970s and the deterioration of the competitiveness of Italian exports in the 1980s, after Italy joined the European Monetary System. ${ }^{61}$

As with Barletta, shoemaking skills existed in San Mauro in the early twentieth century (drawing labour on account of military exemption for artisanal labour in the sector during World War I). In the interwar period local shoemakers established a cooperative under the patronage of the Fascist government, and Mussolini himself donated 88,000 lire $(\$ 84,650 / 2016)$ to promote mechanization of local production in 1939. Various families started their businesses after World War II and introduced industrial techniques in the second half of the 1950s. By the end of

\footnotetext{
${ }^{60}$ Gianfranco Viesti, “L’Abbigliamento nella Puglia Centrale” in Mezzogiorno dei Distretti, ed. Gianfranco Viesti (Rome, 2000): 59-95.

${ }^{61}$ Michele D’Ercole, "Il Distretto Barlettano della Calzatura," in Mezzogiorno, ed. Viesti, 37-58; Michele Fratianni and Franco Spinelli, A Monetary History of Italy (Cambridge, 1997), 235-239.
} 
that decade some of those firms that would later become industry leaders, such as Casadei, Pollini, and Sergio Rossi (all included in the sample analyzed in this article), had established their workshops or small factories. ${ }^{62}$

The 1970s and 1980s were important decades also for San Mauro. Producers strengthened their positions in domestic and international markets, and abandoned the fierce competition in the medium-low segments to focus on medium-high and luxury products. Emphasis was placed on product innovation, high-quality raw materials, and partnerships with fashion designers, in addition to local labour skill upgrading by establishing a vocational training center "The International Footwear School and Research Centre" (Cercal), in 1984. ${ }^{63}$

For a comparison of the two districts we can consider that, in 1971, in the sectors of specialization (footwear and leather goods, and clothing and textiles), Barletta had more than 4,286 employees, whereas San Mauro had 3,318. By 1981 the corresponding figures were 9,610 and 4,735 respectively, and, in 1991, 14,122 and 4,804. ${ }^{64}$ The much lower employment growth in the northeastern district does not indicate stagnation. Barletta's sectors of specialization included footwear and garments, whereas San Mauro remained footwear only. Moreover, the area and workforce of the Barletta district was greater than its northeastern counterpart. In spite of the difference in size, the value of the two districts' exports is similar. ${ }^{65}$ This suggests that San Mauro's production has a higher value added and a greater share serves foreign markets.

\footnotetext{
${ }^{62}$ Roberto Garavini, Franco Calistri, and Ornella Cilona, La Quarta Italia (Rome, 1988), 240-242; http://www.distrettocalzaturesanmauropascoli.it/formazione.asp, accessed on 07/01/2017.

${ }^{63}$ Roberto Garavini, Franco Calistri and Ornella Cilona, La Quarta Italia (Rome, 1988), 240-242.

${ }^{64}$ Data source: Istat, I Censimenti delle Attività Produttive dal 1951 al 1991. Dati Comunali. CD-ROM (Rome, 1998).

${ }^{65}$ The latest available figures refer to 2014. San Mauro's export amounted to $€ 464$ million and Barletta's counterpart was $€ 460$ million.

http://www.osservatoriodistretti.org/sites/default/files/rapporto-2015.pdf accessed on 10/01/2017
} 
To assess the role of government financial subsidies in the critical decades of the 1970s and 1980s, the records of two samples of companies located in each district at the relevant Chambers of Commerce were collected (Bari for Barletta and Forlì for San Mauro). ${ }^{66}$ The two, relatively small samples of companies (fifty-three overall), consist of family-owned enterprises whose legal status is either limited liability or a public company, as these are the only ones legally obliged to disclose their records. The inclusion of those companies alone creates bias in the samples, as the smallest companies in the districts are unlikely to go public, and their records would therefore have not been available. The dataset also includes reports and balance sheets of companies in other manufacturing sectors comparable to those of specialization, so as to obtain samples of appropriate size (see the Appendix for details).

The Barletta and San Mauro samples include thirty-two and twenty-one manufacturing companies respectively, active or public at various times over the two decades. These provide 681 observations (annual balance sheets): 460 for southern companies and 221 for the northeastern sample. The latter is smaller, as the district and the sectors of specialization are smaller than in Barletta. Moreover, companies in the northeastern sample did not have public status or were not trading during the 1971-91 period; most incorporated as, or went, public in the 1980s.

Table 1 below displays information about the size of sample firms. All fall within the definition of a SME applied in the 1970s (scheme 902/76), having fixed net assets below $1.2 \mathrm{bn}$ lire. Since $1.2 \mathrm{bn}$ lire in 1976 prices equals $2.3 \mathrm{bn}$ lire in 1980 prices, even the largest companies in the samples, Cofra in Barletta with fixed assets of 1,849 million and Pollini in San Mauro with fixed assets of 1,646 million, are below the threshold. Moreover, sample firms fall into the European definition of

\footnotetext{
${ }^{66}$ It would have been interesting to cover also the previous decades. However, company records were very limited for the 1950s and 1960s.
} 
SMEs as small firms with fixed net assets and turnover below 10 million Euros, and medium-sized firms with fixed net assets of 10-43 million Euros and turnover of 1050 million Euros. Converting Table 1 into Euros, the fixed assets of the largest firms in both samples do not exceed 4.6 million Euros, and their turnover is below 33.4 million Euros. The EU definition also considers the headcount: small firms employ fewer than 50 workers and medium-sized firms 50-250. However, a systematic comparison of sample firms in terms of employment is not feasible, as companies' annual reports provide only intermittent workforce information. ${ }^{67}$

The firms in the samples are owned by the founders or their descendants. Even public companies did not trade their shares on the stock exchange in the years under analysis, as shown in their balance sheets. This means that these firms comply with the EU's "independence" criterion: no more than 25 percent of the SMEs' capital should be controlled by partner enterprises or public bodies. ${ }^{68}$ Moreover, firms in the samples are "family businesses" as the founders or their descendants are the sole equity-owners and are directly involved in their management. ${ }^{69}$

\footnotetext{
${ }^{67}$ European Commission, Commission Staff Working Document on the implementation of Commission Recommendation of 6 May 2003 concerning the definition of micro, small and medium-sized enterprises (Brussels, 2009).

${ }^{68}$ Ibid.

${ }^{69}$ For a definition of family business see Christina Lubinski, "Path Dependency and Governance in German Family Business,” Business History Review 85, no. 4 (2011): 699-724 and literature therein.
} 


\section{Table 1}

Net capital stock and turnover of firms in the samples, 1971-91.

\begin{tabular}{lcccccccc}
\hline & $\begin{array}{c}\text { Net Capital Stock } \\
\text { m } 1980 \text { lire }\end{array}$ & \multicolumn{2}{c}{$\begin{array}{c}\text { Net Capital Stock } \\
0002016 \$\end{array}$} & \multicolumn{2}{c}{$\begin{array}{c}\text { Turnover } \\
\text { m } 1980 \text { lire }\end{array}$} & \multicolumn{2}{c}{$\begin{array}{c}\text { Turnover } \\
0002016 \$\end{array}$} \\
\hline \multirow{2}{*}{ Barletta } & San & Barletta & San & Barletta & San & Barletta & San \\
& & Mauro & & Mauro & & Mauro & Mauro \\
Range & $12-1,849$ & $8-1,646$ & $32-4,992$ & $22-4,444$ & $55-13,680$ & $49-11,058$ & $148-36,932$ & $132-29,853$ \\
Average & 464 & 307 & 1,253 & 829 & 1,788 & 3,101 & 4,827 & 8,372 \\
Median & 285 & 155 & 769 & 418 & 580 & 1,967 & 1,565 & 5,310 \\
\hline
\end{tabular}

Source: Chamber of Commerce in Bari (henceforth CCB) and Chamber of Commerce in Forlì (henceforth CCF) company records, for full archival reference see the Appendix.

Note: Conversion rates from the Istituto Nazionale di Statistica, Coefficienti per tradurre valori monetari dei periodi sottoindicati in valori del 2016 (Rome, 2017).

Companies in the Barletta sample are, on average, larger in terms of fixed net assets, but have a lower turnover which may reflect the different market segments in which the two districts specialize. The higher level of fixed assets is consistent with the findings of larger studies, which have interpreted this feature of southern SMEs as a distortion caused by the subsidies, as these lowered the cost of capital relative to labor. $^{70}$

Figure 1 below displays the capital structure of companies in the two samples.

\footnotetext{
${ }^{70}$ Filippo Siracusano and Carlo Tresoldi, "Le Piccole Imprese Manifatturiere nel Mezzogiorno: Diseconomie Esterne, Incentivi, Equilibri Gestionali e Finanziari," 112 in Il sistema finanziario nel Mezzogiorno, Numero Speciale dei Contributi all'Analisi Economica, ed. Banca d'Italia (Rome, 1990), 103-167.
} 


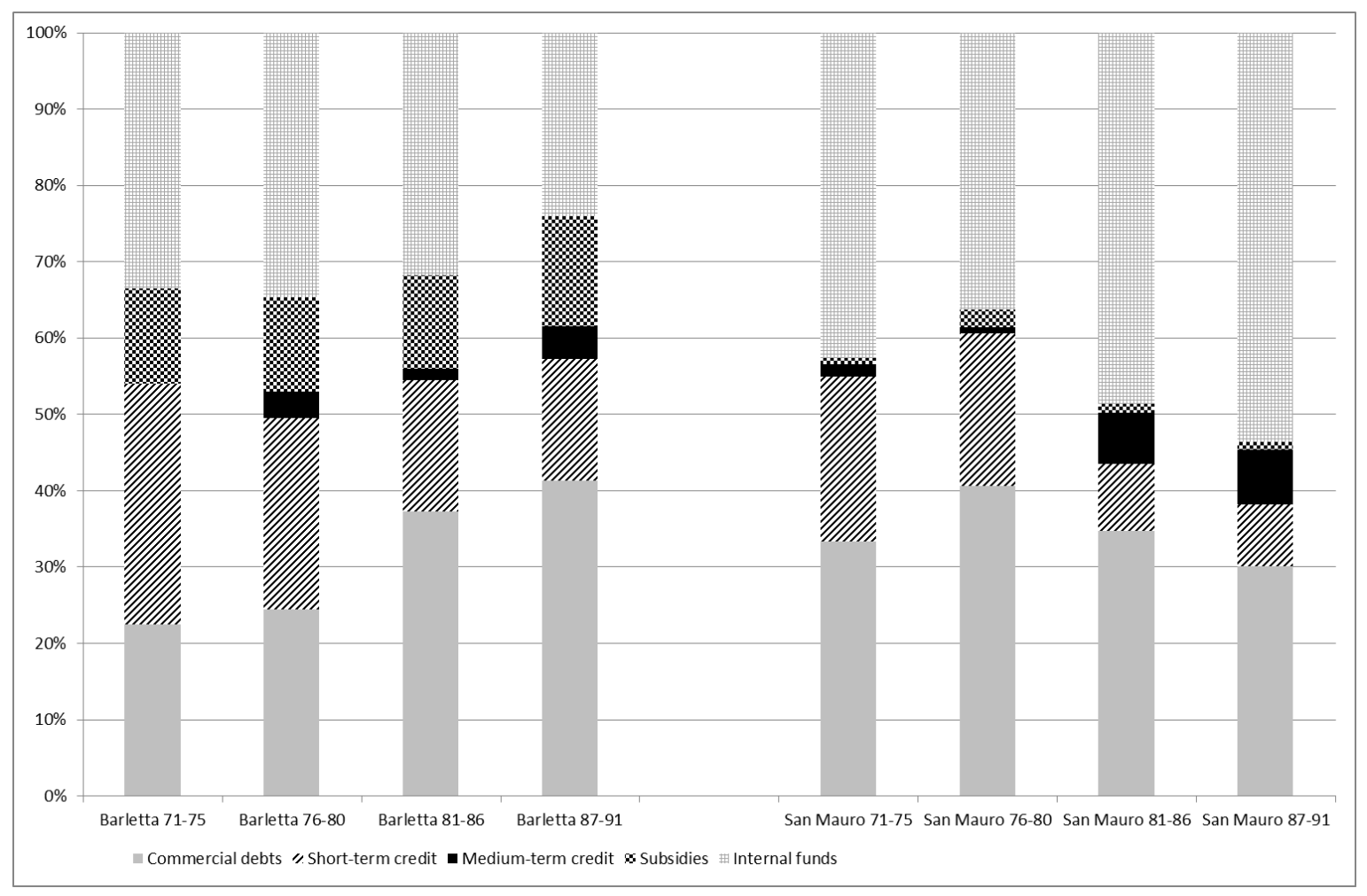

Figure 1. Capital structure of the Barletta and San Mauro samples.

Keys: Medium-term credit includes loans from financial institutions and bonds; internal funds include paid-up capital, contributions from directors and reserves; subsidies include subsidized loans and grants. (Source: CCB company balance sheets and CCF company balance sheets.)

Market finance, either in the form of short- or medium-term credit, is an important component of the sample firms' capital structure. This is consistent with previous studies showing that firms within industrial districts had greater access to market finance, in particular bank credit, as banks and firms are part of the same fabric which reduces information asymmetries between borrowers and lenders, makes it easier for banks to assess borrowers' risk, and prevents moral hazard. ${ }^{71}$

\footnotetext{
${ }^{71}$ Conti and Ferri, "Banche Locali,"; Paolo Finaldi Russo and Paola Rossi, "Credit Constraints in Italian Industrial Districts," Applied Economics 33, no. 11 (2001): 1469-1477; Francesca Carnevali, "Between Markets and Networks: Regional Banks in Italy," Business History 38, no. 3 (1996): 84-100; Joseph E. Stiglitz and Andrew Weiss, "Credit Rationing in Markets with Imperfect Information," American Economic Review 71, no. 3 (1981): 393-410.
} 
Paid-up capital and reserves, included in internal funds, are greater for firms in the northeastern sample, particularly in the 1980s, indicating these firms are more profitable. ${ }^{72}$ Commercial debt is the single most important source of finance in both samples, reflecting the long repayment period of trade credit, on average ninety days. It is also an indicator of the importance of circuits of credit internal to districts. ${ }^{73}$

Government subsidies, including grants and soft loans, are clearly more important for firms in the southern sample than for their northeastern counterpart. This situation reflects the more generous subsidies available in the South and the limited availability of market medium-term finance. The literature assessing the importance and impact of government subsidies is extensive, and certain studies have focused on SMEs. A study by the Mediocredito, including a sample of 3,852 across all manufacturing sectors between 1989 and 1991, found that, overall, 53 percent of firms in the sample received subsidies, with the South being above the national average at 58.9 percent. ${ }^{74}$ Other researchers have examined additional impacts of financial subsidies on small businesses. ${ }^{75}$ However, none of these studies differentiate between SMEs located within districts and those elsewhere, nor do they clarify whether district firms have preferential access to subsidies. Moreover, no studies have yet provided an insight into the importance of subsidies for firms within districts, which is a gap this research aims to fill.

\footnotetext{
${ }^{72}$ For a more detailed discussion of the capital structure see Anna Spadavecchia, "Financing Industrial," 569-593.

${ }^{73}$ Dei Ottati, "Trust, Interlinking Transactions".

${ }^{74}$ Michele Bagella, Gli Incentivi di Politica Industriale: Presupposti Teorici e Valutazioni Empiriche, Osservatorio sulle Piccole e Medie Imprese Quaderni di Politica Industriale n. 21 (Roma, 1998).

${ }^{75}$ Giovanni Trovato and Marco Alfò, "Credit Rationing and the Financial Structure of Italian Small and Medium Enterprises," Journal of Applied Economics 9, no. 1 (2006): 167-184; Gianfranco E. Atzeni and Oliviero A. Carboni, "The Effects of Subsidies on Investment: An Empirical Evaluation on ICT in Italy," Revue de l'OFCE 97 bis (2006): 279-302.
} 
Bagella and Caggese argue that soft loans and grants can be considered effective if the profitability of recipient firms increases, not only while these receive the subsidies, but also subsequently, when they are no longer subsidized. Firms should move from position 1 in Figure 2 below, characterized by low and highly variable profit, to position 2 , with higher and less variable profit, when receiving subsidies. This should happen because subsidies increase the recipient companies' profits and reduce the variability of profits - an indicator of risk - by providing an additional, less variable, inflow of funds. ${ }^{76}$ Furthermore, firms are learning organizations, and recipient companies should learn how to conduct their business better while in the subsidized stage. ${ }^{77}$ This methodology has never been applied in full because of a want of longitudinal company records, something that this historical research provides.

\footnotetext{
${ }^{76}$ Bagella and Caggese, "Struttura del Capitale."

77 This aspect is studied in work on learning by doing. See for instance Naomi R. Lamoureaux, Daniel M.G. Raff, and Peter Temin ed., Learning by Doing in Markets, Firms, and Countries (Chicago, 1999).
} 


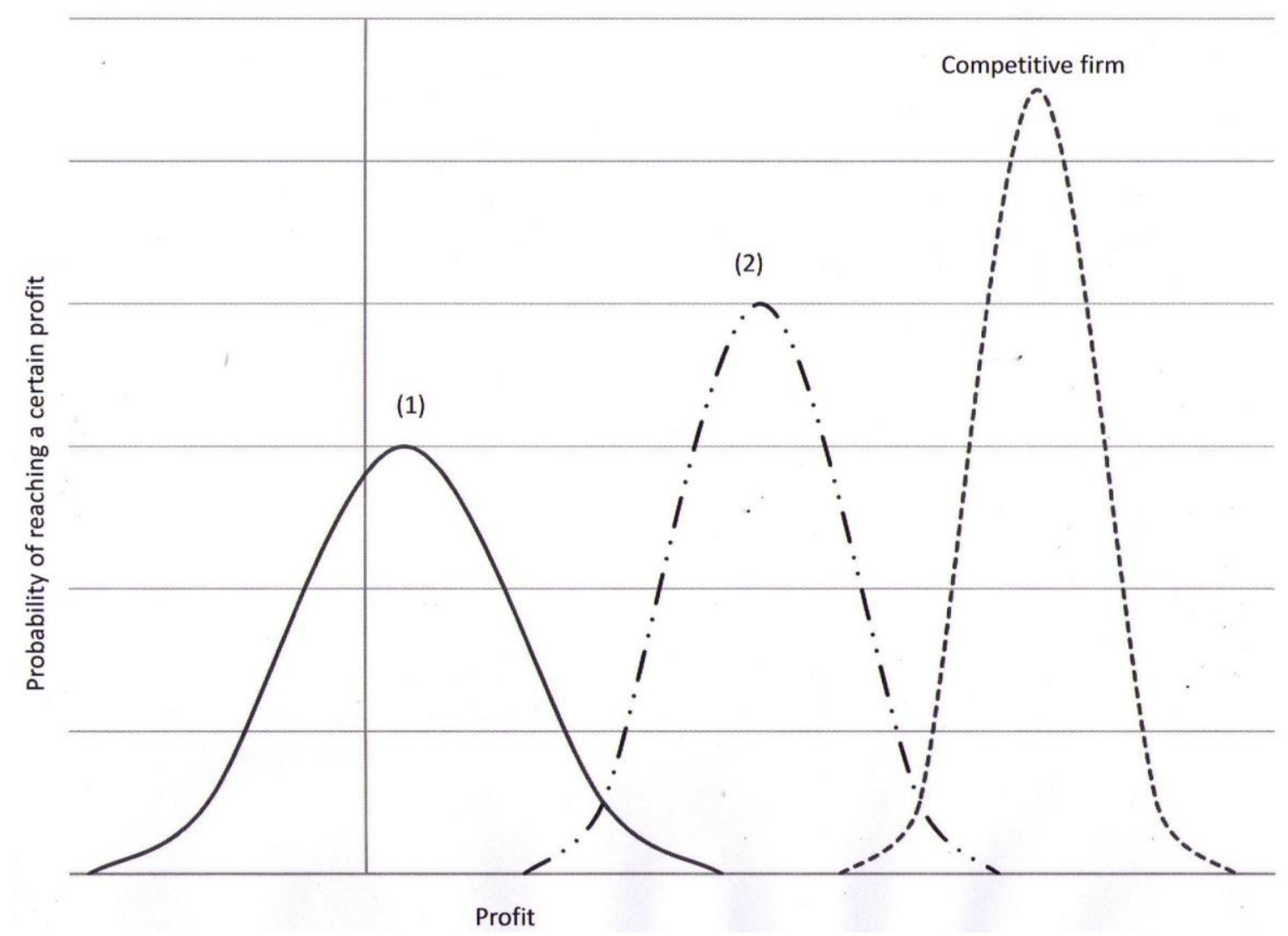

Figure 2. Profitability and risk of subsidized and non-subsidized firms: the ideal scenario Keys: position (1) = low and highly variable profit; position $(2)=$ higher and less variable profit; competitive firm = ideal position characterized by even higher and less variable profit. (Source: adapted from Bagella and Caggese, "Struttura del Capitale," 836.)

The companies' performance in the post-subsidy stage is of critical importance. For them to return to position 1 would mean that their profitability could improve only by constant subsidies, entailing a permanent capture of government funds and, in extreme cases, the bailing out of troubled firms, which are unwanted policy outcomes. Moreover, if the company returned to position 1 it would be perceived by banks as a "bad company" and would be credit-rationed, whereas if it remained in position 2, or moved to the ideal position of "competitive firm," it would not be credit-rationed again. A caveat related to this methodology is that it does not account for factors other than subsidies in the performance of recipient firms, and does not aim to quantify a cause-effect relationship between subsidies and firms' performance. 
Table 2 looks at the profitability of firms in the two samples, using two measures: return on equity and rate of return. The variability of these financial ratios, indicated by the coefficients of variation in brackets, is a standard indicator of risk. ${ }^{78}$ The division into stages of the companies' life reduces the number of observations available for each sub-period used in Figure 1; therefore, it is appropriate to study the sample firms in the whole 1971-91 period.

\footnotetext{
${ }^{78}$ Richard A. Brealey and Stewart C. Myers, Principles of Corporate Finance (Boston, 2003), 187219. Table 2 displays coefficients of variation as these are more appropriate than standard deviations for comparing different samples.
} 
Table 2

Profitability, Barletta and San Mauro samples, 1971-91

(weighted averages, coefficient of variation in brackets)

\begin{tabular}{|c|c|c|c|c|c|}
\hline & Firms $^{\mathrm{a}}$ & $\begin{array}{l}\text { Firm age } \\
\text { (average) }\end{array}$ & $\begin{array}{l}\text { Return on } \\
\text { equities }^{b}\end{array}$ & $\begin{array}{l}\text { Long term capital \% } \\
\text { fixed net } \\
\text { assets }^{\mathrm{c}}\end{array}$ & $\begin{array}{l}\text { Equity \% fixed } \\
\text { net assets }{ }^{d}\end{array}$ \\
\hline \multicolumn{6}{|l|}{ Barletta } \\
\hline Pre-subsidy & 16 & 3.5 & $0.6(3.35)$ & 74.4 & 72.1 \\
\hline Subsidized & $26(3)$ & 12.1 & $5.1(2.7)$ & 116.4 & 92.2 \\
\hline Post-subsidy & $6(2)$ & 17.9 & $0.2(1.02)$ & 100.7 & 93.5 \\
\hline $\begin{array}{l}\text { Never } \\
\text { subsidized }\end{array}$ & $6(4)$ & 7.6 & $11.2(7.7)$ & 126.7 & 91.5 \\
\hline \multicolumn{6}{|l|}{ San Mauro } \\
\hline Pre-subsidy & 4 & 9.0 & $4.3(1.6)$ & 135.5 & 130.3 \\
\hline Subsidized & $11(2)$ & 18.0 & $12.0(1.2)$ & 222.0 & 177.6 \\
\hline Post-subsidy & 4 & 19.7 & $15.3(0.7)$ & 256.8 & 220.5 \\
\hline $\begin{array}{l}\text { Never } \\
\text { subsidized }^{\text {e }}\end{array}$ & $9(4)$ & 7.9 & $12.8(1.8)$ & 250.8 & 166.5 \\
\hline
\end{tabular}

\section{Gap between San Mauro and Barletta}

Pre-subsidy

61.1

58.2

Subsidized

105.6

85.4

Post-subsidy

15.1

156.1

127

Never subsidized

1.6

124.1

75

Source: CCB and CCF company balance sheets.

Note: differences in means have been tested for significance: in the subsidized and post-subsidy groups the level of significance is either $1 \%$ or $5 \%$ depending on the specific ratio and percentage; in the presubsidy and never-subsidized groups the levels of significance are either $5 \%$ or $10 \%$.

The gap between San Mauro and Barletta has been computed as the difference between the weighted averages of the two samples.

Keys:

a: number of companies in each group. Number of failed companies in each group in brackets;

b: return on equities defined as profit (or losses) divided by equities (weighted average);

c: long-term capital as a percentage of fixed net assets;

$\mathrm{d}$ : equity as a percentage of fixed net assets;

e: "never subsidized" companies (excluding bankrupt companies' final year of activity). 
Companies in the subsidized stage are older, indicating the difficulty of securing subsidies in the early stage of their activity. This is confirmed by previous studies and reflects the involvement of credit institutions in handling subsidies. These institutions are cautious in extending loans to new businesses, preferring companies with a proven track record.

Overall, firms in the southern sample display lower and more variable profits, that is higher risk, than their northeastern counterparts, a result confirmed by studies based on larger samples. ${ }^{79}$ This is not surprising, considering that firms in the Barletta district trade in lower value-added products. The annual reports of the southern firms often mentioned low, if not declining, growth in local and national markets, which limited their ability to exploit economies of scale and, in turn, might have dictated a lower utilization of production capacity. ${ }^{80}$ Only the largest companies in the southern sample, such as Damato and Cofra, mentioned exporting to Britain, whereas the reports of northeastern firms such as Casadei, Rossi, and Pollini frequently mentioned exporting to Northern Europe, Japan, and the United States. ${ }^{81}$ The southern textile firms Tucci and Ripatex also mentioned owning obsolete equipment and having related expenses for repairs, as well as difficulties in procuring spare parts..$^{82}$ Other studies have taken an "ecosystem" approach and pointed out the detrimental effects on the southern economy of macroeconomic and institutional factors, such as poorer infrastructure, inefficiency of the public administration and rigidities in the labor market, such as national wages..$^{83}$

\footnotetext{
${ }^{79}$ Siracusano and Tresoldi, "Le Piccole"; Bagella and Caggese, "Struttura del Capitale."

${ }^{80}$ For example CCB company records Sbia, Sfi, Sga, Sto various years.

${ }^{81}$ CCB company records Scof, various years; CCF company records Nca, Nfr, Npn, Npo, Nrs, various years.

${ }^{82}$ CCB company records Stu and Sri, various years.

${ }^{83}$ Riccardo Faini, Gianpaolo Galli and Curzio Giannini, "Finance and Development: The Case of Southern Italy," in Finance and Development: Issues and Experience, ed. Alberto Giovannini (Cambridge, 1992), 158-214; Emanuele Felice, Perchè il Sud E'Rimasto Indietro (Bologna, 2015).
} 
Southern sample companies shift from low profitability and high risk before subsidies, to higher profitability and lower risk when subsidized. In the post-subsidy stage they become much less profitable and less risky, displaying values below those of the pre-subsidy stage. Therefore, from position 2 in the Figure, they do not progress to the ideal position of the "competitive firm," but retreat beyond the initial position 1 occupied in the pre-subsidy stage.

Companies in the northeastern sample display the "ideal" behavior. They move from position 1 before subsidies to position 2 when subsidized, and in the postsubsidy stage they move closer to the "competitive firm" position. Thus, the profitability gap between firms in the two samples not only increases when they receive subsidies, but increases even further in the post-subsidy period. The "never subsidized" groups display the smallest profitability gap, due to the high-profit and high-risk strategy of the southern sample. This clearly entails a higher probability of failure, as also indicated by the high number of failed companies (in brackets in the Firms column). Despite not relying on subsidies, these firms display high levels of long-term capital as a percentage of fixed net assets. Their main sources of long-term borrowed capital are the partners themselves.

The comparison in Table 2 casts doubt on the effectiveness of subsidies. Southern companies with access to subsidies seem to pursue a "survival" strategy, whereas unsubsidized ones pursue a "profit maximizing" strategy. It could be argued that southern entrepreneurs prefer to reap benefits from institutions and abandon the market rationale in a particularly difficult market due to competition from various fronts, including the black economy. ${ }^{84}$ However, this may not be necessarily the case, and the behavior of firms in the southern sample may be economically rational. The

\footnotetext{
${ }^{84}$ Trigiglia, Sviluppo, 93-94.
} 
low capitalization of southern companies and particularly the scarcity of companyowned capital (indicated by equity as a percentage of fixed net assets in Table 2), suggest that southern companies would have very little capital to cover possible losses from riskier, though more profitable, projects. Therefore, as long as they can increase their profits artificially through subsidies, undertaking low-profit and low-risk projects can be the most economically rational choice, where the economic rationale is the survival of the firm. The propensity for a low-profit and low-risk strategy also aligns with various studies on developing economies. These have documented how the shortage of liquid assets, such as cash that can be drawn on in case of emergency, makes households in developing economies choose a low-risk and low-return crop. Moreover, firms faced with high, and to some extent uninsurable, risk, trade off lower for more stable profits. ${ }^{85}$

The literature on family businesses sheds further light on the low-profit and low-risk strategy observed here. ${ }^{86}$ Family firms facing a high-risk ecosystem may prioritize survival over profit maximization, in order to ensure continuity of the family legacy for themselves and future generations. This leads to a long-term orientation in investment decisions, even though this in turn might result in lower short-term returns. ${ }^{87}$

\section{CONCLUSION}

\footnotetext{
85 See for instance Stefan Dercon, "Risk, Crop Choice, and Savings: Evidence from Tanzania," Economic Development and Cultural Change 44, no. 3 (1996): 485-513; Arne Bigsten and Måns Söderbom, "What Have We learned from a Decade of Manufacturing Enterprise Survey in Africa?" The World Bank Research Observer 21 (Fall 2006): 241-265.

${ }^{86}$ Firms in the sample can be considered as family businesses as they are owned by the founderentrepreneurs or their descendants, and these are involved in the running of the business.

${ }^{87}$ Andrea Colli, "Risk, Uncertainty, and Family Ownership," in The Endurance of Family Businesses: A Global Overview, ed. Paloma Fernandez Perez and Andrea Colli (Cambridge, 2013), 85-108; Mark Casson, "The Economics of the Family Firm," Scandinavian Economic History Review 47, no. 1 (1999): 10-23; James J. Chrisman, Jess H. Chua, Allison W. Pearson and Tim Barnett, "Family Involvement, Family Influence, and Family-Centered Non-Economic Goals in Small Firms," Entrepreneurship Theory and Practice 36, no. 2 (2012): 267-293.
} 
This article has challenged the thesis that national policies have had a negligible, if not detrimental, influence on the growth of districts in the second half of the twentieth century. Focusing on Italy, this research has explored the importance of financial subsidies for recipient firms within two districts in the 1970s and 1980s. Soft loans and grants represented a greater source of finance in the southern sample of Barletta than in the northeastern district of San Mauro. Considering that the second half of the 1970s and the early 1980s were years of restructuring in both districts, it can be concluded that in the case of the northeastern district, government subsidies contributed to growth, but in the case of the southern district, these subsidies played a critical role in financing the restructuring which led to its growth. Nevertheless, government funds were more effective in San Mauro than in Barletta, in that the profitability of recipient firms increased there in the post-subsidy period, and not in Barletta. Small firms in the southern sampe became less risky and more profitable when subsidized, but reverted to lower profitability when they were no longer subsidized. An even more striking indication is displayed by the never subsidized group, which shows higher levels of both profitability and risk than the other southern groups, suggesting that firms, when subsidized, pursue a "survival" strategy which can be economically rational in the high-risk ecosystem they face.

Two contrasting profiles of subsidised firms emerge from the analysis in this article: the subsidy-reliant, and the subsidy-strengthened, enterprise. The former profile is dominant in the Barletta sample and the latter in San Mauro. The figure below provides a snapshot of the firms' profiles, and factors affecting the different impact of subsidies on the two samples, determining the profitability gap between them. The characteristics highlighted below are not exhaustive and refer only to those emerging from the analysis in this article. 
Subsidy-reliant enterprises

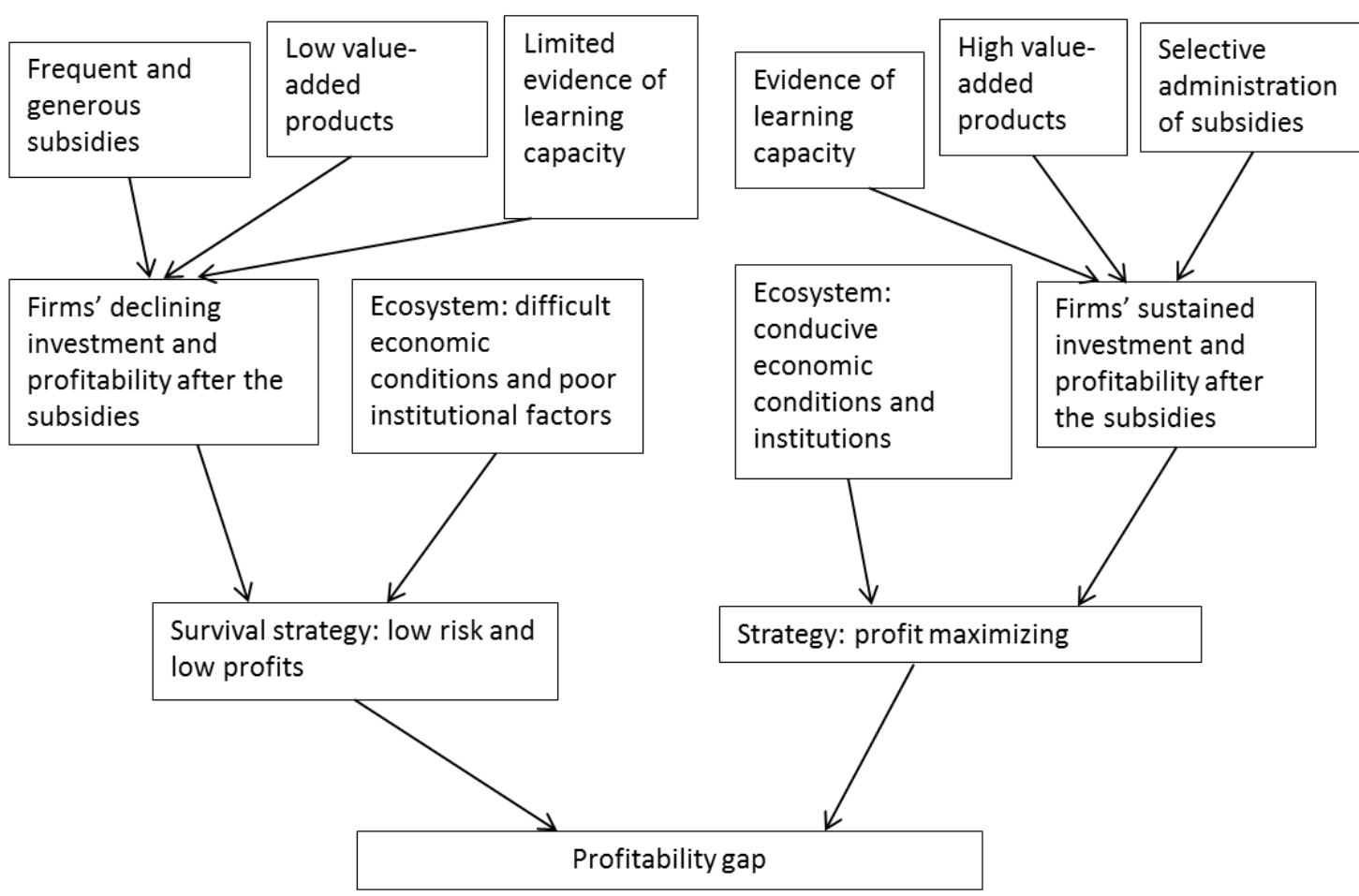

Subsidy-strengthened enterprises

Figure 3: Profiles of subsidised enterprises and the profitability gap. (Source: text)

This research deepens our knowledge of the behavior of districts. Italian and international historiography has emphasized the important role of local institutions in the growth of districts. These were important in the resolution of disputes and market regulation, and in providing technical education and quality control. ${ }^{88}$ This research demonstrates that national institutions were also important, and sheds lights on a type of finance, i.e. soft loans and grants, largely overlooked in the literature on Italian districts.

${ }^{88}$ See for instance Charles F. Sabel and Jonathan Zeitlin, "Introduction," p.24 in World of Possibilities ed. Sabel and Zeitlin, 1-33; Francesca Carnevali, "Crooks, Thieves, and Receivers: Transaction Costs in Nineteenth-century Industrial Birmingham," The Economic History Review 57, no 3 (2004): 533550; Hashino and Kurosawa, "Beyon Marshallian Agglomeration;" Brusco, "The Emilian Model;" Michael Best, The New Competition: Institutions of Industrial Restructuring (Cambridge, 1990), 203226; Alberto Rinaldi, 'The Emilian Model Revisited: Twenty Years After,' Business History 47, no.2 (2005): 244-266; Hubert Schmitz 'Industrial Districts: Model and Reality in Baden-Wurttember' in Industrial Districts and Local Economic Regeneration, ed. Frank Pyke and Werner Sengenberger (Geneva, 1992): 87-121 
The importance of investigating the impact of financial subsidies for SMEs on the growth of districts also stems from the wide diffusion of these policies. As mentioned in the Introduction, several countries launched such schemes in the postwar era. Accounts of the development of the engineering district of Ota in Japan confirm their importance. The district emerged in the 1950s and grew rapidly, becoming an important manufacturer of auto parts. Government support enabled the upgrading of small businesses' equipment and machinery in Ota as firms could secure subsidized long-term funds, which also crowded-in market credit. ${ }^{89}$ A further example is the high-tech cluster of Sakaki, where almost every firm employing fewer than twenty employees benefited from government support, and one third of all companies received government funds for the purchase of numerically controlled equipment. ${ }^{90}$

The US government also took policy initiatives to help SMEs in the 1950s with the SBA and the Small Business Investment Corporations (SBICs) to ensure supply of long-term and equity capital to small businesses. ${ }^{91}$ Private investors, as well as institutions such as the Bank of America, established SBICs in Silicon Valley, and these grew rapidly from 1959 to 1968 . However, the role of the SBICs as funders of high-tech firms was short-lived, as in the late 1960s venture capitalists opted for alternative forms of incorporation..$^{22}$

Research highlights a different type of federal policy as crucial for the development of this cluster, i.e. federal military spending and demand for electronics, space vehicles, communications technology, and computer programs. ${ }^{93}$ Thus, while

\footnotetext{
${ }^{89}$ Konosuke Odaka, "Evaluating Japanese Industrial Policy: The Auto-Parts Industry Example," in Small Firms, Large Concerns, ed. Odaka and Sawai, 290-306; D.H. Whittaker, Small Firms in the Japanese Economy (Cambridge, 1997), 164-179.

${ }^{90}$ David Friedman, The Misunderstood Miracle: Industrial Development and Political Change in Japan (Ithaca and London, 1988) 187-194.

${ }^{91}$ Boutin, "Small Business Loans"; Blackford, A History of Small Business, 135 and 165-168

${ }^{92}$ Kenney and Florida, "Venture Capital" 106-109; AnnaLee Saxenian, Regional Advantage: Culture and Competition in Silicon Valley and Route 128, (Cambridge, Mass., 1996), 26-27.

${ }^{93}$ Timothy J. Sturgeon, "How Silicon Valley Came to Be" in Understanding Silicon Valley, ed.
} 
the American policy of financial support for SMEs was only of limited importance for Silicon Valley, a different facet of government policy was of paramount importance.

This historical analysis of the contribution of financial subsidies to the development of districts and clusters addresses a gap lamented also in research dealing with contemporary clusters. Lehamann and Menter emphasize that "While the conditions for creating clusters and modalities of how clusters should be configured have been investigated intensively, evidence about the performance evaluation of public cluster policy is scarce."94 Their research shows that financial support for clusters initiated by the German government in 2007 improved their productivity, but suggests that the policy was "picking winners," i.e. highly competitive firms and clusters which did not need public resources. ${ }^{95}$ Conversely, studies on the impact of the French cluster policy, launched in 1998, found that financial incentives did not have a significant effect on firms' productivity. Their analysis suggests that policy was captured by declining sectors and firms. ${ }^{96}$ Both types of drawbacks, i.e. "picking winners" and "bailing out" troubled firms can be observed particularly in the case of the southern district of Barletta, where both top performing firms and unprofitable businesses managed to capture government subsidies for long periods of time, which casts doubt on the management of such financial incentives.

This research refines our understanding of the broader institutional context of the development of districts. While it disputes that macroeconomic institutions have not favored the growth of districts, this article supports one of the fundamental tenets

Kenney, 15-47; Stuart W. Leslie, “The Biggest 'Angel' of Them All; The Military and the Making of Silicon Valley” in Understanding Silicon Valley, ed. Kenney, 48-67; Saxenian, Regional Advantage, 20-27; Blackford, A History, 157-160.

${ }^{94}$ Erik E. Lehmann and Matthias Menter "Public cluster policy and performance," The Journal of Technology Transfer 43, no. 3 (2018): 558-592.

${ }^{95}$ Ibid.

${ }^{96}$ Philippe Martin, Thierry Mayer, and Florian Mayneris, "Public Support to Clusters. A Firm Level Study of French 'Local Productive Systems'," Regional Science and Urban Economics 41, no.2 (2011): 108-123. 
of the "historical alternatives" approach, that the organization of production is shaped by politically defined economic and social interests. The Italian case, and other examples discussed in this article, clarify that national policies have contributed, to varying degrees, to the development of districts. Nevertheless, policies alone cannot guarantee the emergence of districts. They are an enabling factor, but the ecosystem in which districts are embedded provides impetus for learning and growth. 


\section{Appendix}

Records at the Chamber of Commerce in Bari

\begin{tabular}{|c|c|c|c|c|c|c|}
\hline \multirow[t]{2}{*}{ Folder No } & \multirow[t]{2}{*}{ Company } & \multirow[t]{2}{*}{ Legal status } & \multirow[t]{2}{*}{ Established } & \multicolumn{2}{|c|}{ Records available } & \multirow[t]{2}{*}{ Product } \\
\hline & & & & From & To & \\
\hline 826 & San & $\mathrm{Pb} / \operatorname{Ltd}(1988)$ & 1936 & 1951 & 1991 & Food processing \\
\hline 1,786 & Sma & $\mathrm{Pb}$ & 1959 & 1959 & 1976 & Clothing \\
\hline 2,140 & Svr & Ltd & 1967 & 1967 & 1991 & Food processing \\
\hline 2,191 & Sin & Ltd & 1967 & 1968 & 1989 & Food processing \\
\hline 2,169 & Ser & Ltd & $1 / 1967$ & 1969 & 1985 & Wood processing \\
\hline 2,442 & Sfi & Ltd & $1 / 1971$ & 1971 & 1991 & Textiles \\
\hline 2,564 & Sbc & Ltd & $1 / 1972$ & 1972 & 1991 & Textiles \\
\hline 3,603 & Stu & $\begin{array}{l}\text { Pv/Ltd } \\
(12 / 1977)\end{array}$ & 3/1972 & 1978 & 1991 & Wood processing \\
\hline 2,635 & Svc & Ltd & 11/ 1972 & 1973 & 1991 & Food processing \\
\hline 2,614 & Sfs & Ltd & $11 / 1972$ & 1973 & 1985 & Textiles \\
\hline 2,674 & Sab & Ltd /Pv (1986) & $2 / 1973$ & 1973 & 1986 & Footwear \\
\hline 2,690 & San & Ltd & $3 / 1973$ & 1973 & 1983 & Clothing \\
\hline 2,645 & Sbia & $\mathrm{Pb}$ & 1973 & 1973 & 1991 & Clothing \\
\hline 2,632 & Sal & Ltd & 1973 & 1973 & 1979 & Clothing \\
\hline 2,586 & Sar & Ltd & 1973 & 1973 & 1988 & Footwear \\
\hline 2,749 & Sri & $\mathrm{Pb}$ & 10/ 1973 & 1974 & 1991 & Footwear \\
\hline 2,769 & Sst & $\mathrm{Pb}$ & $11 / 1973$ & 1974 & 1990 & Plastic \\
\hline 2,788 & Spl & $\begin{array}{l}\text { Pv/Ltd } \\
\text { (4/1984) }\end{array}$ & $12 / 1973$ & 1984 & 1991 & Footwear \\
\hline 2,840 & Sca & Ltd & 3/1974 & 1974 & 1987 & Footwear \\
\hline 2,888 & Sil & Ltd & $6 / 1974$ & 1975 & 1989 & Wood processing \\
\hline 3,094 & Smo & Ltd & $11 / 1975$ & 1976 & 1981 & Clothing \\
\hline 3,400 & Sga & Ltd & $3 / 1977$ & 1979 & 1991 & Footwear \\
\hline 3,479 & Sto & Ltd & 10/ 1977 & 1978 & 1991 & Footwear \\
\hline 3,546 & Sbim & Ltd & $11 / 1977$ & 1978 & 1991 & Clothing \\
\hline 3,593 & Ste & Ltd & $12 / 1977$ & 1978 & 1991 & Footwear \\
\hline 4,165 & $\mathrm{Sec}$ & Ltd & $1 / 1980$ & 1980 & 1991 & Footwear \\
\hline 4,427 & Sja & Ltd & $9 / 1980$ & 1980 & 1991 & Clothing \\
\hline 4,790 & Sli & Ltd & $6 / 1981$ & 1981 & 1991 & Footwear \\
\hline 4,110 & Spo & Pv/Ltd (1983) & 1979 & 1983 & 1988 & Footwear \\
\hline 5,491 & Sro & Ltd & 1983 & 1983 & 1991 & Footwear \\
\hline 5,475 & Ssa & Ltd & 2/1983 & 1983 & 1991 & Footwear \\
\hline 4,600 & Sco & $\begin{array}{c}\text { Pv/Ltd } \\
(6 / 1984)\end{array}$ & $3 / 1981$ & 1984 & 1991 & Footwear \\
\hline
\end{tabular}

Keys: $\mathrm{Pv}=$ Private partnership; Ltd $=$ Limited liabilities; $\mathrm{Pb}=$ Public share. 
Records at the Chamber of Commerce in Forlì

\begin{tabular}{|c|c|c|c|c|c|c|}
\hline Folder $n$. & Company & Legal status & Established & $\begin{array}{l}\text { Reco } \\
\text { from }\end{array}$ & $\begin{array}{l}\text { vailable } \\
\text { to }\end{array}$ & Product \\
\hline 2,996 & Nla & Ltd/Pv (1966-71) & 1955 & 1956 & $1991 *$ & Footwear \\
\hline 3,751 & Nde & $\mathrm{Pb}$ & 1962 & 1963 & 1967 & Fotwear \\
\hline 4,442 & Nci & Pv/Ltd (10/1974) & $7 / 1968$ & 1974 & 1991 & Metal chairs \\
\hline 5,676 & $\mathrm{Neu}$ & Ltd & $3 / 1974$ & 1974 & 1991 & $\begin{array}{l}\text { Footwear } \\
\text { equipment }\end{array}$ \\
\hline 5,212 & Nrs & $\mathrm{Pv} / \mathrm{Pb}(12 / 1975)$ & $4 / 1967$ & 1976 & 1991 & Footwear \\
\hline 5,581 & Nwi & Ltd & $12 / 1973$ & 1974 & 1979 & Footwear \\
\hline 7,280 & Nma & Ltd & 2/1978 & 1978 & 1987 & Footwear \\
\hline 8,146 & Nal & $\mathrm{Pb}$ & 9/1979 & 1979 & 1991 & Clothing \\
\hline 8,367 & Nca & $\mathrm{Pv} / \mathrm{Pb}(2 / 1980)$ & 9/1966 & 1981 & 1991 & Footwear \\
\hline 4,935 & Npo & $\mathrm{Pv} / \mathrm{Pb}(12 / 1980)$ & $2 / 1972$ & 1981 & 1991 & Footwear \\
\hline 3,484 & $\mathrm{Nfa}$ & $\mathrm{Pv} / \mathrm{Pb}(4 / 1981)$ & $1 / 1961$ & 1981 & 1991 & Footwear \\
\hline 4,662 & $\mathrm{Nfr}$ & $\mathrm{Pv} / \mathrm{Pb}(6 / 1982)$ & $2 / 1970$ & 1982 & 1991 & Clothing \\
\hline 10,471 & Nri & Ltd & $6 / 1982$ & 1982 & 1991 & Footwear \\
\hline 10,417 & Nrf & Ltd & $5 / 1982$ & 1982 & 1991 & Leather items \\
\hline 4,351 & Nvi & Pv/Ltd (11/1982) & $8 / 1967$ & 1983 & 1985 & Footwear \\
\hline 6,934 & Nrm & Pv/Ltd (2/1983) & $6 / 1969$ & 1983 & 1987 & Clothing \\
\hline 11,850 & Npn & $\operatorname{Ltd}$ & $4 / 1984$ & 1984 & 1991 & Footwear \\
\hline 5,325 & Nrt & $\mathrm{Pv} / \operatorname{Ltd}(9 / 1985)$ & $4 / 1973$ & 1985 & 1991 & $\begin{array}{l}\text { Paper/card } \\
\text { boxes }\end{array}$ \\
\hline 12,904 & Nti & Ltd & $4 / 1985$ & 1985 & 1991 & Footwear \\
\hline 11,263 & Nip & Pv/Ltd (5/1989) & 9/1983 & 1989 & 1991 & Packaging \\
\hline 13,580 & $\mathrm{Npl}$ & Pv/Ltd (7/1989) & $12 / 1985$ & 1989 & 1991 & Leather items \\
\hline
\end{tabular}

Keys as above; * excluding 1966-71 and 1973. 